\title{
Pathological Changes in Gut and Liver Due to Dietary Inclusion of Betaine and Chromium Pico Linate in Nile Tilapia Fish
}

\author{
Walaa F Awadin ${ }^{*}$, Abeer E Aziza ${ }^{2}$ \\ ${ }^{1}$ Department of Pathology, Faculty of Veterinary Medicine, Mansoura University, Egypt \\ ${ }^{2}$ Department of Nutrition and Nutritional Deficiency Diseases, Faculty of Veterinary Medicine, Mansoura University, Egypt
}

*Corresponding author: Walaa F Awadin,Running head of Pathology Department, Faculty of Veterinary Medicine, Mansoura University, Egypt. Tel: +201126797600; Fax:+20502379952; Email: walaafekriawadin@yahoo.com.

Citation: Awadin WF, Aziza AE (2017) Pathological Changes in Gut and Liver Due to Dietary Inclusion of Betaine and Chromium Pico Linate in Nile Tilapia Fish. J Fish Aqua Dev: JFAD-119. DOI:10.29011/JFAD-119/100019

Received Date: : 10 August, 2017; Accepted Date: 25 August, 2017; Published Date: 4 September, 2017

\begin{abstract}
A complementary study was conducted to investigate histomorphometric changesin gut and liver due todietary supplementation of betaine and chromiumpicolinate ( $\mathrm{Cr}$ - Pic) or blend of them in Nile tilapia. Fish were divided into four groups; first group was fed a $\mathrm{Cr}$ - Pic or betaine free basal diet, other three groups were fed on basal diet supplemented with $800 \mu \mathrm{g} / \mathrm{kg}$ $\mathrm{Cr}-\mathrm{Pic}, 10 \mathrm{~g} / \mathrm{kg}$ of betaine and betaine $+\mathrm{Cr}-\mathrm{Pic}(10 \mathrm{~g} / \mathrm{kg}$ of betaine and $800 \mu \mathrm{g} \mathrm{Cr}-\mathrm{Pic})$. Morphometric measurements made in the intestine included counting numbers of Goblet Cells (GCs), Eosinophilic Granulocytes (EGs) and IntraEpithelial Lymphocytes (IEL), villous height, height of the enterocytes $(\mathrm{EH})$ and thickness of muscular coat. Histomorphometric analysis showed that betaine increased number of GCs and IEL. Cr-Pic increased number of GCs, EGs andthickness of muscular coat.Betaine+Cr-Pic increased number of EGs, length of EH, villous height, perimeter and area, thickness of muscular coatand decreased Hepatocytes/Nuclear $(\mathrm{H} / \mathrm{N})$ ratio. We concluded that the dietary inclusion of both betaine and Cr-Pic was beneficial for liver and gut health in Nile tilapia.
\end{abstract}

Keywords: Betaine; Chrome; Fish; Liver; Pathology

\section{Introduction}

The effect of dietary inclusion of betaine and chromium picolinate (Cr-Pic) in Nile Tilapia fish was recently studied by Aziza and her co-workers[1].Concluding that, combination between betaine and $\mathrm{Cr}-\mathrm{Pic}$ could be used as a good growth promoting feed additives for Nile tilapia. This study was complementary to the first part of their research to investigate the effect of betaine, $\mathrm{Cr}$-Pic and betaine $+\mathrm{Cr}$-Pic supplementation on histomorphometric changesin gut and liver. Previous research conducted on villus morphology illustrated that villus morphology is governed by enteral nutrient absorption[2].Betaine has been reportedto increase the number of IntraEpithelial Lymphocyte (IEL) and thickness of lamina propria [3]; decrease the crypt/villus ratio[4]in healthy and coccidian-infected chicks.Chromium $(\mathrm{Cr})$ is an essential micro-mineral because it plays important role in nutritional and physiological responses on fish [5,6]; commonly found in the environment in trivalent $\mathrm{Cr}$ (III) and hexavalent $\mathrm{Cr}$ (VI) forms[7]. Various trivalent chromate compounds have been used as feed additives in fish diet because of their participation in carbohydrate, protein and fat metabolism [6,8]. Cr-Pic is the most popular form of trivalent $\mathrm{Cr}$ (III) [9]. It is generally accepted that organic $\mathrm{Cr}$ sources such as $\mathrm{Cr}-\mathrm{Pic}$, chelated $\mathrm{Cr}$, amino acid-Cr complexes and yeast-incorporated $\mathrm{Cr}$ have more bioavailability than inorganic sources $[10,11]$. There has been an increasing interest in the potential effect of dietary $\mathrm{Cr}$ on growth performance of hybrid tilapia (O. niloticus XO. aureus) [12,13], carbohydrate utilization in hybrid tilapia $(O$. niloticus $X O$. aureus $)$ $[11,8,13]$, immune status in O. mossambicus [14] and toxicity in largemouth bass (Micropterus salmoides) [15]. Our work was designed to compare between effects of betaine, chromium, betaine plus chromium on gut and liver health in Nile tilapia.

\section{Materials and methods}

\section{Diet preparation}

Four isonitrogenous $(32 \% \mathrm{CP})$ isocaloric $(3000 \mathrm{Kcal} \mathrm{DE}$ Kg-1) diets were formulated (Table 1) 


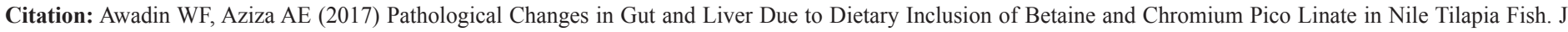
Fish Aqua Dev: JFAD-119.

\begin{tabular}{|c|c|c|c|c|}
\hline \multicolumn{5}{|c|}{ Dietary treatment } \\
\hline Ingredients & Control & Cr-Pic & Betaine & Betaine+Cr-Pic \\
\hline Yellow corn & 31 & 31 & 31 & 31 \\
\hline Soybean meal & 20 & 20 & 20 & 20 \\
\hline Fish meal & 25.5 & 25.5 & 25.4 & 25.4 \\
\hline Corn glutein & 3.2 & 3.2 & 3.2 & 3.2 \\
\hline Wheat bran & 9 & 9 & 9 & 9 \\
\hline Wheat flour & 7 & 7 & 7 & 7 \\
\hline Oil & 3 & 3 & 3 & 3 \\
\hline $\begin{array}{c}\text { Vitamin \& Mineral } \\
\text { premixa }\end{array}$ & 1 & 1 & 1 & 1 \\
\hline Salt & 0.3 & 0.3 & 0.3 & 0.3 \\
\hline Chromium $(\mu \mathrm{g})$ & 0 & 800 & 0 & 800 \\
\hline Betaine $(\mathrm{g})$ & 0 & 0 & 10 & 10 \\
\hline \multicolumn{5}{|c|}{ Chemical composition\% (analyses) } \\
\hline Crude protein & 31.94 & 31.56 & 31.85 & 32 \\
\hline Ether extract & 7 & 7.21 & 7.13 & 7.2 \\
\hline Ash & 8.17 & 7.83 & 8.16 & 8.5 \\
\hline
\end{tabular}

Table 1: Ingredients and nutrients composition of the experimental diet.

A Trace minerals \& vitamins premixes were prepared to cover the levels of the micro minerals\& vitamins 2 for tilapia fish as recommend-ed by (NRC, 1993). Vitamins premix (IU or $\mathrm{mg} / \mathrm{kg}$ diet); vit. A 5000, Vit. 3D3 1000, vit. E 20, vit. k3 2, vit. B1 2, vit. B2 5, vit. B6 1.5, vit. B12 0.02, Pantothenic acid 10, Folic acid 41, Biotin 0.15, Niacid 30. Mineral mixture (mg/kg diet); Fe 40, Mn $80, \mathrm{Cu} 4, \mathrm{Zn} 50$, I 0.5 , Co $0.2 \&$ Se 50.2. to satisfy the nutritional requirements of Nile tilapia (O. niloticus) [16]. The first diet assigned as the basal control (without 106 supplementations of $\mathrm{Cr}$ pic or betaine). Three experimental diets were supplemented with $800 \mu \mathrm{g}$ of $104 \mathrm{Cr}$-pic $\mathrm{kg}$ of diet, $10 \mathrm{~g}$ of betaine/ $\mathrm{kg}$ of diet or mixture of $800 \mu \mathrm{g}$ of Cr-pic and $10 \mathrm{~g}$ ofbetaine $\mathrm{kg}$ diet-1; respectively. Diets were prepared in the form of water stable sinking pellet and stored in plastic bags in refrigerator during the time of use.

\section{Experimental Design}

One hundred and eighty fish with initial weight of $(42 \pm 1.5$ g) were received and distributed in 8 glass aquaria $(80 \mathrm{~cm}$ length, $35 \mathrm{~cm}$ width $\& 40 \mathrm{~cm}$ height). Triplicate aquarium tanks were assigned (45 fish/group). Fish fed at 3\% body weight twice daily (9.00-10.00 $\mathrm{h}$ and 15.00-16.00 h) for 7 weeks; the experimental

period. Fish were subjected to a photoperiod regimen of 12-13 h light and 12-11 $\mathrm{h}$ dark/ day and the temperature during the experimental period ranged from $24-27^{\circ} \mathrm{C}$. Daily cleaning for each aquarium was carried out with partial replacement of water by previously stored (for 48 hours) DE chlorinated tap water. The work described is in compliance with the guidelines of the Ethical committee of Mansoura University.

\section{Morphometric and histopathological examination}

For histological appraisal, 3 fish were allocated per tank $(\mathrm{n}=6$ per treatment) and sacrificed at the end of the experimental period. Tissue specimens were collected from liver and the three parts of the intestine, proximal part, middle part and distal part then fixed in $10 \%$ buffered formalin. Subsequently, the specimens were dehydrated in a graded ethanol series and then embedded in paraffin wax. All sections were cut at four $\mu \mathrm{m}$ and stained with Hematoxylin and Eosin (H\&E). Images of intestine and liver were captured with an Olympus BX41 microscope supplied with a DVC $1300 \mathrm{C}$ color digital camera. Histometric measurements were applied on tissue sections from intestine and liver using an image analysis (image $\mathrm{J}=\mathrm{http}: / /$ imagej.en.softonic.com). Measurements made in the intestine included: a) villous height $(\mathrm{H}), \mathrm{b}$ ) villous perimeter, c) villous area, d) number of Goblet Cells (GCs) [17,18],e) number of IntraEpithelial Lymphocytes (IEL) infiltrated into the epithelial layer across a standardized distance of 100 enterocytes (only nucleated cells) [19], f)height of the enterocytes were taken at tip of the mucosal folds [20],g)width of lamina propria, h) eosinophilic granulocytes (EGs) were totally counted in the lamina propria of the intestine and compared between control and experimental fish[21,22]andthickness of muscular coat. Values of (a-f) used for analysis were the means of the highest 5 folds per section. Partly or fully fused two folds were treated as one. Meanwhile, measurements made in the liver included nuclear ratio (estimated in 50 hepatocytes per section) [20].

\section{Statistical analysis}

Data were expressed as means \pm standard error. Statistical analysis was performed using the software. All morphometric variables were tested by student $T$ test to compare between control and experimental groups. Differences between means were compared using Duncan's multiple range test at significance of differences $(p<0.05)$ among dietary treatments.

\section{Results}

Data of morphometric analysis of three intestinal parts were demonstrated in (Table 2). 


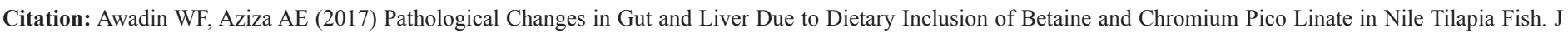
Fish Aqua Dev: JFAD-119.

\begin{tabular}{|c|c|c|c|c|c|}
\hline & \multirow{2}{*}{ Parameters } & Group 1 & Group 2 & Group 3 & Group 4 Betaine \\
\hline & & Control & Betaine & Chromium & chromium \\
\hline \multirow{9}{*}{ Proximal } & Number of goblet cells & $7.61 \pm 1.40$ & $9.20 \pm 1.09$ & $5.28 \pm 0.71$ & $7.80 \pm 0.80$ \\
\hline & Number of IEL & $0.48 \pm 0.15^{\mathrm{a}}$ & $0.56 \pm 0.15^{\mathrm{ab}}$ & $0.24 \pm 0.10^{\mathrm{ab}}$ & $0.04 \pm 0.04^{b}$ \\
\hline & Number of EGs & $10.50 \pm 4.41 \mathrm{~b}$ & $61.60 \pm 30.60^{\mathrm{ab}}$ & $19.60 \pm 11.96^{\mathrm{ab}}$ & $104 \pm 30.75^{\mathrm{a}}$ \\
\hline & Height & $1560 \pm 37.58^{\mathrm{a}}$ & $1645 \pm 49.24^{\mathrm{a}}$ & $1272 \pm 27.74^{\mathrm{b}}$ & $1657 \pm 48.26^{\mathrm{a}}$ \\
\hline & $\mathrm{EH}$ (um) & $110.9 \pm 1.74^{\mathrm{a}}$ & $99.93 \pm 1.49^{\mathrm{b}}$ & $104.3 \pm 1.57^{\mathrm{c}}$ & $115.1 \pm 1.63^{\mathrm{a}}$ \\
\hline & Perimeter & $3661 \pm 365.8^{a}$ & $3824 \pm 150.2^{\mathrm{a}}$ & $2970 \pm 77.86^{b}$ & $3862 \pm 146.8^{\mathrm{a}}$ \\
\hline & Area & $7542 \pm 300.9^{\mathrm{a}}$ & $8126 \pm 322^{\mathrm{a}}$ & $6368 \pm 174^{\mathrm{b}}$ & $8320 \pm 313.8^{a}$ \\
\hline & Width of lamina propria & $232.9 \pm 11.58^{\mathrm{a}}$ & $280.5 \pm 11.79^{b}$ & $244.5 \pm 9.56^{\mathrm{a}}$ & $249.7 \pm 12.9^{\mathrm{a}}$ \\
\hline & Thickness of the muscle & $134.3 \pm 8.33^{\mathrm{a}}$ & $148.4 \pm 5.10^{\mathrm{a}}$ & $150.1 \pm 7.06^{\mathrm{a}}$ & $180.8 \pm 8.32^{b}$ \\
\hline \multirow{9}{*}{ Middle } & Number of goblet cells & $1.72 \pm 0.43^{\mathrm{a}}$ & $8.75 \pm 1.27^{\mathrm{b}}$ & $9.72 \pm 0.88^{\mathrm{b}}$ & $2.90 \pm 1.10^{\mathrm{a}}$ \\
\hline & Number of IEL & $0.04 \pm 0.04^{\mathrm{ab}}$ & $0.25 \pm 0.10^{\mathrm{a}}$ & $0.12 \pm 0.05^{\mathrm{b}}$ & $00^{\mathrm{b}}$ \\
\hline & Number of EGs & $2.80 \pm 1.15$ & $28 \pm 16.66$ & $10.13 \pm 5.73$ & $80.75 \pm 17.08$ \\
\hline & Height & $911.3 \pm 33.14^{\mathrm{c}}$ & $1049 \pm 28.62^{b}$ & $1054 \pm 40.19^{b}$ & $1235 \pm 60.27^{\mathrm{a}}$ \\
\hline & $\mathrm{EH}$ & $108.9 \pm 3.67^{\mathrm{a}}$ & $83.76 \pm 1.71^{\mathrm{b}}$ & $82.75 \pm 2.67^{b}$ & $113.9 \pm 2.65^{\mathrm{a}}$ \\
\hline & Perimeter & $2575 \pm 137.2$ & $2625 \pm 161$ & $2595 \pm 183$ & $2796 \pm 130.4$ \\
\hline & Area & $5471 \pm 306.3$ & $5719 \pm 348.9$ & $5584 \pm 393$ & $6030 \pm 271.6$ \\
\hline & Width of lamina propria & $232.7 \pm 11.21^{\mathrm{a}}$ & $235.9 \pm 16.92^{\mathrm{a}}$ & $279.5 \pm 22.62^{\mathrm{a}}$ & $570.1 \pm 68.76^{\mathrm{b}}$ \\
\hline & Thickness of muscle & $118.4 \pm 11.19^{\mathrm{a}}$ & $145.9 \pm 7.46^{\mathrm{ab}}$ & $147.5 \pm 10.87^{\mathrm{ab}}$ & $168.4 \pm 6.18^{\mathrm{b}}$ \\
\hline \multirow{10}{*}{ Distal } & Number of goblet cells & $1.46 \pm 0.60^{\mathrm{a}}$ & $8 \pm 1.77^{\mathrm{b}}$ & $7.70 \pm 0.77^{\mathrm{b}}$ & $5.38 \pm 0.81^{\mathrm{b}}$ \\
\hline & Number of IEL & $0.26 \pm 0.11$ & $0.40 \pm 0.19$ & $0.22 \pm 0.14$ & $0.09 \pm 0.06$ \\
\hline & Number of EGs & $5.75 \pm 2.17^{\mathrm{b}}$ & $27.25 \pm 9.87^{\mathrm{ab}}$ & $244.5 \pm 110.5^{\mathrm{a}}$ & $95.5 \pm 39.85^{\mathrm{ab}}$ \\
\hline & $\mathrm{EH}$ & $74.94 \pm 2.20^{c}$ & $87.10 \pm 2.16^{\mathrm{b}}$ & $82.29 \pm 2.08 b^{c}$ & $125.8 \pm 4.59^{\mathrm{a}}$ \\
\hline & Height & $696.6 \pm 28.59^{\mathrm{a}}$ & $766.9 \pm 27.78^{\mathrm{a}}$ & $753.4 \pm 36.20^{\mathrm{a}}$ & $928.9 \pm 46.96^{b}$ \\
\hline & Perimeter & $1870 \pm 95.15$ & $2063 \pm 166.7$ & $2178 \pm 134.5$ & $2359 \pm 178.7$ \\
\hline & Area & $4010 \pm 209.8$ & $4622 \pm 264$ & $4433 \pm 375.4$ & $4788 \pm 291.1$ \\
\hline & Width of lamina propria & $259.8 \pm 12.98^{\mathrm{a}}$ & $262.2 \pm 25.14^{\mathrm{a}}$ & $348.3 \pm 23.28^{\mathrm{b}}$ & $285.6 \pm 19.30^{\mathrm{ab}}$ \\
\hline & Thickness of muscle & $103 \pm 5.51^{\mathrm{a}}$ & $117.7 \pm 8.02^{\mathrm{a}}$ & $166.1 \pm 13.44^{\mathrm{b}}$ & $165.5 \pm 8.72^{\mathrm{b}}$ \\
\hline & \multicolumn{5}{|c|}{ Values are means \pm SE. Small superscript letters indicate significance when $\mathrm{P}<0.05$} \\
\hline
\end{tabular}

Table 2: Morphometric analysis of the proximal, middle and distal intestine of fish from control and experimental groups.

Number of GCs non-significantly increased in proximal part of betaine group and in middle and distal parts of Cr-Pic group. Number of IEL non-significantly elevated in three intestinal segments of betaine group when compared with control group.Number of EGs showed a non-significant increase in proximal and middle parts of betaine+Cr-Pic group and in distal part of Cr-Pic group when compared with control group. Villous height, perimeter and area were the highest in three intestinal segments of betaine+Cr-Pic groups. $\mathrm{EH}$ was the longest in three parts of betaine+Cr-Pic group when compared with other groups. Measurements of width of lamina propria showed variation among different experimental groups in three intestinal segments. Thickness of muscular coat significantly rose in proximal and middle parts of betaine+Cr-Pic group and indistal partofCr-Pic group when compared with control group.Histological illustration of intestinal villi, enterocytes, IEL, GCs and EGs were shown in (Figure 1, 2, and 3). 


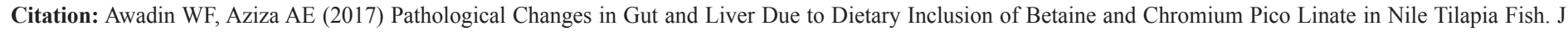
Fish Aqua Dev: JFAD-119.

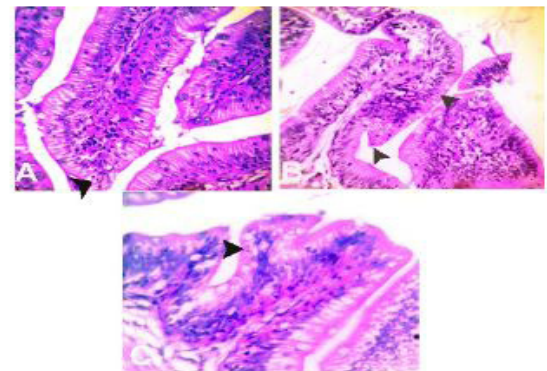

Figure 1 (A-C): A: Proximal part, B: middle part and C: distal part of intestine from betaine group. Arrowheads point to IEL (H\&E: A\&B x 200, C, x 250).

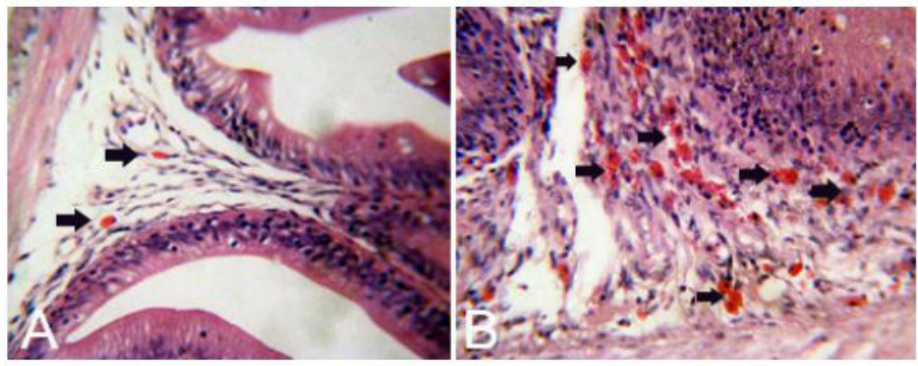

Figure 2 (A\&B): A: Intestine from control group shows few EGs in lamina propria (arrows) when compared with $\mathbf{B}$ : high EGs population in lamina propria (arrow) Cr-Pic group (H\&E, x 200).
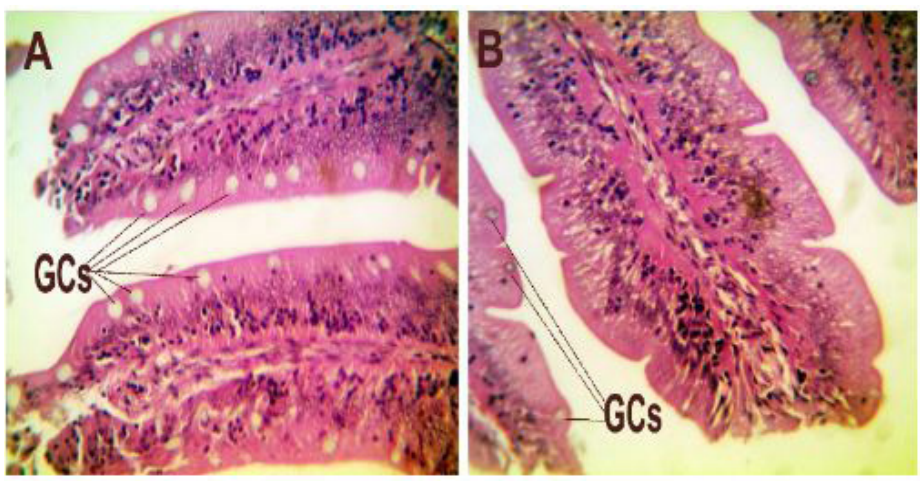

Figure 3 (A\&B): A: proximal intestine from control group shows high number of goblet cells (GCs) in betaine group when compared with $\mathbf{B}$ : few GCs in Cr-Pic group (H\&E, x 200).

In liver, slight non-significant increase in hepatocyte nuclear ratio was recorded in group of fish supplemented with betaine when compared with other groups. However, the lowest value of hepatocyte nuclear ratio was shown in group of fish supplemented with betaine $+\mathrm{Cr}-\mathrm{Pic}$ (Figure 4).

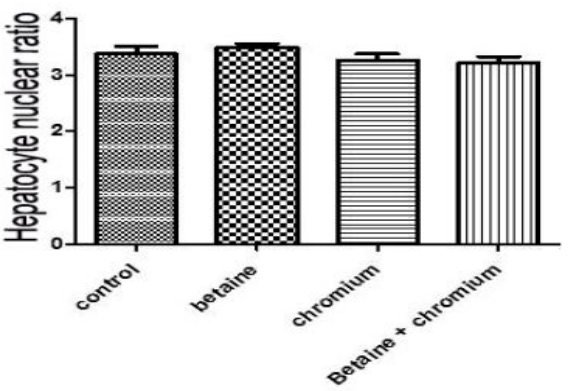

Figure 4: Effect of different treatments on hepatocyte nuclear ratio.

\section{Discussion}

Betaine (trimethylglycine) is a naturally occurring amino acid derivative found in a variety of foodstuffs of plant and animal origin and has two primary metabolic roles; a methyl group donor and an osmolyte [23]. Betaine is added to farmed fish feed as an osmolyte to assist in cellular water homeostasis and to protect fish from the stress of moving from low to high salinity [23]. Several studies previously indicated that dietary Cr-supplementation improved cellular and humoral responses in mammals [24-27] and birds [28-31]. Collectively, our results showed increase numbers of GCs and IEL in betaine group, numbers of GCs, EGs and thickness of muscular coat in $\mathrm{Cr}-\mathrm{Pic}$ group. Meanwhile, in betaine+Cr-Pic group number of EGs, length of EH, villous height, perimeter and area, thickness of muscular coat were increased and $\mathrm{H} / \mathrm{N}$ ratio was decreased. Thus, the most measured parameters in intestine were increased by dietary inclusion of both $\mathrm{Cr}$-Pic and betaine. The increased number of EGs in three parts of intestine was suggested to be related with $\mathrm{Cr}$-Pic. Inhalation of particulate forms of $\mathrm{Cr}$ (VI) may augment the severity of ongoing allergic asthma in human, as well as alter its phenotype [32]. More research is needed to declare the relationship between $\mathrm{Cr}$-Pic and EGs in fish. In liver, there was slight non-significant increase in hepatocytes size in fish fed on betaine only which can be considered an indicator of a well-fed status rather than a nutritional disorder. Betaine is a lipotrope that prevents or reduces accumulation of fat in the liver. One hypothesis regarding the lipotropic properties of betaine is that it contains an electrophilic methyl group that ameliorates pathologic states induced by reductive and oxidative stress [33]. Cr-Pic alone or with betaine in the diet slightly and insignificantly decreased size of the hepatocytes. It was found that dietary $\mathrm{Cr}$-Pic significantly lowered carcass lipid content in grass carp (C. idellus) [6,34] so it may decrease liver lipid content as well. Betaine+Cr-Pic could be used as a good growth promoting and betaine reduced the adverse effects of $\mathrm{Cr}$ on hematological and biochemical parameters [1]. 
Citation: Awadin WF, Aziza AE (2017) Pathological Changes in Gut and Liver Due to Dietary Inclusion of Betaine and Chromium Pico Linate in Nile Tilapia Fish. J Fish Aqua Dev: JFAD-119.

\section{Conclusion}

- Dietary inclusion of both Cr-Pic and betaine increased length of EH, villous height, perimeter and area, thickness of muscular coat

- Dietary inclusion of both Cr-Pic and betaine increased number of EGs

- Dietary inclusion of both betaine and Cr-Pic was better than being separately

\section{References}

1. Aziza A, Zahran E, Elseady Y (2015) Dietary supplementation of Nile tilapia (Oreochromis niloticus) with betaine, chromium picolinate and a combination: Effects on growth performance, hematological and biochemical parameters. Ann Vet An Sci: 2(4).

2. Tarachai P, Yamauchi K (2000) Effects of luminal nutrient absorption, intraluminal physical stimulation, and intravenous parenteral alimentation on the recovery responses of duodenal villus morphology following feed withdrawal in chickens. Poult Sci 79: 1578-1585.

3. Klasing KC, Adler KL, Remus JC, Calvert CC (2002) Dietary betaine increases intraepithelial lymphocytes in the doudenum of coccidia infected chicks and increases functional properties of phagocytes. $J$ Nutr 132: 2274-2282.

4. Kettunen H, Tiihonena K, Peuranena S, Saarinena MT, Remusb JC (2001) Dietary betaine accumulates in the liver and intestinal tissue and stabilizes the intestinal epithelial structure in healthy and coccidiainfected broiler chicks. Comp. Biochem Physiol 130: 759-769.

5. Kucukbay FZ, Yazlak H, Sahin N, Cakmak MN (2006) Effects of dietary chromium picolinate supplementation on serum glucose, cholesterol and minerals of rainbow trout (Oncorhynchus mykiss). Aquac Int 14: 259-266.

6. Liu T, Yuan D, Gao P, Zhao Y (2010) Effect of dietary chromium picolinate on growth performance and blood parameters in grass carp fingerling, Ctenopharyngodon idellus. Fish Physiol Biochem 36: 565-572.

7. Bagchi D, Stohs Si. J, Downs BW, Bagchi M, Preuss HG (2002) Cytotoxicity and oxidative mechanisms of different forms of chromium. Toxicol 180: 5-22.

8. Pan Q, Liu S, Zheng C, Bi YZ I2002a) The effect of chromium nicotinic acid on growth, feed efficiency and tissue composition in hybrid tilapia (Oreochromis niloticus X O. aureus). Acta Hydrobiology Sinica 26: 197-200.

9. Nutrition Business International Supplement Business Report (NBI) (2001) Nutrition Business Journal, 9 (3) San Diego California, USA.

10. Shiau SY, Liang HS (1995) Carbohydrate utilization and digestibility by tilapia, Oreochromis niloticus, HO. aureus are affected by chromium oxide inclusion in the diet. J Nutr 125: 976-982.

11. Shiau SY, Shy SM (1998) Dietary chromic oxide inclusion level required maximize glucose utilization in hybrid tilapia, Oreochromis niloticus HO. aureus. Aquac 161: 357-364.

12. Pan Q, Bi YZ, Yan XL, Pu YY, Zheng C (2002b) Effect of organic chromium on carbohydrate utilization in hybrid tilapia (Oreochromis niloticus X O. aureus). Acta Hydrobiology Sinica 26: 393-399.
13. Pan Q, Liu S, Tan Y, Bi Y (2003) The effect of chromium picolinate on growth and carbohydrate utilization in tilapia, Oreochromis niloticus and Oreochromis aureus. Aquac 225: 421-429.

14. Arunkumar RI, Rajasekaran P, Michael RD (2000) Differential effect of chromium compounds on the Immune response of the African mouth breeder Oreochromis mossambicus (Peters). Fish Shellfish Immunol 10: 667-676.

15. Kuykendall JR, Miller KL, Mellinger KN, Cain AV (2006) Waterborne and dietary hexavalent chromium exposure causes DNA-protein crosslink (DPX) formation in erythrocytes of largemouth bass (Micropterus salmoides). Aqua Toxicol 78: 27-31.

16. National Research Council (NRC) (1993) Nutrient, Requirements of Fish. National Academy 469 pp.

17. Lundstedt LM, Melo JFB, Moraes G (2004) Digestive enzymes and metabolical profile of Pseudoplatystoma corruscans (Teleostei: Siluriformes) in response to diet composition. Comp Biochem.Physiol 137B: 331-339.

18. Rašković B, Stanković M, Dulić Z, Marković Z, Lakić N, et al. (2009) Effects of different source and level of protein in feed mixtures on liver and intestine histology of the common carp (Cyprinus carpio, Linnaeus, 1758). Comp Biochem Physiol a-Mol \& Integr Physiol 153A: S112-S112.

19. Ferguson RMW, Merrifield DL, Harper GM, Rawling MD, Mustafa S, et al. (2010) The effect of Pedi coccus acidilactici on the gut microbiota and immune status of on-growing red tilapia (Oreochromis niloticus). J Appl Microbiol 109: 851-862.

20. Marković Z, Poleksić V, Dulić Z, Stanković M (2009) Carp production intensification in traditional semi-intensive culture systems by application of extruded feed and selected fish fry. Aquaculture Europe, August 14-17, Trondheim, Norway, Book of Abstracts: 498-499.

21. Gargiulo AM, Ceccarelli P, Dall'Aglio C, Pedini V (1998) Histology and ultrastructure of the gut of the tilapia (Tilapia spp.), a hybrid teleost. Anatomia Histologia Embryologia 27: 89-94.

22. Picchietti S, Fausto AM, Randelli E, Carnevali O, Taddei AR, et al. (2009) Early treatment with Lactobacillus delbrueckii strain induces an increase in intestinal T-cells and granulocytes and modulates immunerelated genes of larval Dicentrarchus labrax (L.). Fish and Shellfish Immunol 26: 368-376.

23. Kidd MT, Ferket PR, Garlich JD (1997) Nutritional and osmoregulatory functions of betaine. World Poult Sci J 53: 125-139.

24. Chang X, Mowat DN (1992) Supplemental chromium for stressed and growing feeder calves. J Anim Sci 70: 559-565.

25. Burton JL, Mallard BA, Mowat DN (1993) Effects of supplemental chromium on immune responses of periparturient and early lactation dairy cows. J Anim Sci 71: 1532-1539.

26. Mathison GW, Engstrom DF (1995) Chromium and protein supplements for growing finishing beef steers fed barley-based diets. Can. J Anim Sci 75: 549-548.

27. Burton JL, Nonnecke BJ, Dubeski PL, Elsasser TH, Mallard BA (1996) Effects of supplemental chromium on production of cytokines by mitogen-stimulated bovine peripheral blood mononuclear cells. J Dairy Sci 79: 2237. 
Citation: Awadin WF, Aziza AE (2017) Pathological Changes in Gut and Liver Due to Dietary Inclusion of Betaine and Chromium Pico Linate in Nile Tilapia Fish. J Fish Aqua Dev: JFAD-119.

28. Uyanik F, Atasever A, Ozdamara S, Aydin F (2002) Effect of dietary chromium chloride supplementation on performance, some serum parameters and immune response in broilers. Biol Trace Elem Res 90: 99-115.

29. JiYue C, Kui L, Xiao Cong L, YaXin Z (2004) Effects of florfenicol and chromium (III) on humoral immune response in chicks. Asian-Austr. J Anim Sci 17: 366-370.

30. Lee T, Yuan D, Gao P, Zhao Y (2010) Effects of chromium picolinate of growth performance and immune responses of broilers. Asian-Austr. $J$ Anim Sci 16: 227-233

31. Bhagat J, Ahmed KA, Tyagi P, Saxena M, Saxena VK (2008) Effects of supplemental chromium on interferon-y (IFN-y) mRNA expression in response to Newcastle disease vaccine in broiler chicken. Res Vet Sci 85: 46-51.
32. Schneider BC, Constant SL, Patierno SR, Jurjus RA, Ceryak SM (2012) Exposure to particulate hexavalent chromium exacerbates allergic asthma pathology. Toxicol. Appl. Pharmacol 259: 38-44.

33. Ghyczy M, Boros M (2001) Electrophilic methyl groups present in the diet ameliorate pathological states induced by reductive and oxidative stress: a hypothesis. Br J Nutr 85: 409-414.

34. Mehrim Al (2012) Effect of Dietary Chromium Picolinate Supplementation on Growth Performance, Carcass Composition and Organs Indices of Nile Tilapia (Oreochromis niloticus L.) Fingerlings. J Fisheries Aqua Sci 7: 224-232. 